\title{
Tensile strength retention of resorptive suture materials applied in the stomach wall - an in vitro study
}

\author{
Mario Kreszinger ${ }^{1 *}$, Bojan Toholj ${ }^{2}$, Aleksandar Ačanski², Sebastijan Baloš $\check{\check{z}}^{3}$, \\ Marko Cincović ${ }^{2}$, Marko Pećin ${ }^{1}$, Marija Lipar ${ }^{1}$, and Ozren Smolec ${ }^{1}$
}

${ }^{I}$ Clinic for Surgery, Orthopaedics and Ophthalmology, Faculty of Veterinary Medicine, University of Zagreb, Zagreb, Croatia

${ }^{2}$ Department for Veterinary Medicine, Faculty of Agriculture, University of Novi Sad, Novi Sad, Serbia

${ }^{3}$ Department of Production Engineering, Faculty of Technical Sciences, University of Novi Sad, Novi Sad, Serbia

KRESZINGER, M., B. TOHOLJ, A. AČANSKI, S. BALOŠ, M. CINCOVIĆ, M. PECIN, M. LIPAR, O. SMOLEC: Tensile strength retention of resorptive suture materials applied in the stomach wall - an in vitro study. Vet. arhiv 88, 235-243, 2018.

\section{ABSTRACT}

The primary objective of this study was to determine whether polyglyconate or polydioxanone resorptive surgical materials are superior in terms of tensile strength retention in implantation in the cadaveric submucosa of the stomach wall. A secondary objective was to compare the tensile strength retention, in the same conditions, of polydioxanone suture materials produced by different manufacturers. Five samples of resorptive suture materials (polyglyconate $\left(\right.$ Maxon $^{\circledR}$, Covidien), polydioxanone $\left(\mathrm{PDS}^{\circledR}\right.$, Ethicon, PDX ${ }^{\circledR}$ Kruuse, Surgicryl ${ }^{\circledR}$ SMI), Catgut chromic, Kruuse) all diameter USP 2-0, were incubated in vitro in the cadaveric submucosa of the stomach wall for fifty days. Measurements of tensile strength were made on day 0 and the $10^{\text {th }}$ day. Polyglyconate (Maxon ${ }^{\mathbb{E}}$ ) showed the greatest initial tensile strength. After 10 days of incubation in the submucosa of the stomach, the tensile strength decreases more rapidly for polyglyconate $\left(\operatorname{Maxon}^{\circledR}\right)$ in comparison to polydioxanone sutures, but they were still higher compared with the others on the $10^{\text {th }}$ day. Polydioxanone Surgicryl ${ }^{\circledR}$ had the highest tensile strength retention - $91.4 \%$ after 10 days of incubation in the submucosa of the stomach. Polydioxanone PDX $^{\circledR}$ maintained only $58.5 \%$ of its initial tensile strength. Polydioxanone Surgicryl ${ }^{\circledR}$ had the highest initial Young's modulus.

Key words: resorptive suture material; polyglyconate; polydioxanone; tensile strength retention; stomach wall

\footnotetext{
*Corresponding author:

Prof. Mario Kreszinger, PhD, DVM., Faculty of Veterinary Medicine, University of Zagreb, Heinzelova 55, 10000 Zagreb, Croatia, Phone: +385 12390 391; Fax: +385 12390 380; E-mail: kreszinger@vef.hr
} 
M. Kreszinger et al.: Tensile strength retention of resorptive suture materials applied in the stomach wall - in vitro study

\section{Introduction}

The function of sutures is to hold tissue in apposition and to support the tissue in opposing all physiological forces during the period of healing (LAMBORN et al., 1970). Different tissues require a different period of healing to achieve the sufficient strength. For an organ that contains free hydrochloric acid and potent proteolytic enzymes, the stomach and intestines heal surprisingly quickly. Stomach and intestine wounds attain maximum strength within 14 to 21 days postoperatively, and have a peak rate of collagen synthesis at 5 days (FINN, 1981). In that period, collagen formation increases tissue strength, while the tensile strength of implanted sutures gradually decreases. Equilibrium of the dynamics of these two processes is important for achieving adequate tissue healing (SMEAK, 1998). The effect of different enzymes, digestive factors and different acidity might induce changes to the tensile strength of suture materials (SCHILLER et al., 1993).

Polyglyconate and polydioxanone are monofilament synthetic sutures that have the strongest initial tensile strength of all sutures, except stainless steel (ROUSH, 2002; GREENWALD et al., 1994). Maxon and PDS retained a larger percentage of tensile strength during a long postoperative period (SANZ et al., 1988).

Monofilament absorbable sutures, polydioxanone and polyglyconate, usually USP 2-0 or 3-0 in size, are recommended suture material for closure of the stomach and intestines (FAHIE, 2014). Polydioxanone (PDS II ${ }^{\circledR}$ Ethicon) sutures have been formulated to minimize the variability of tensile strength retention and absorption rate (loss of mass), and to provide wound support through an extended healing period. The surgeon's choice of suture material for tissue closure is based on its properties, including its initial tensile strength, duration of tensile strength retention, and deformability (SHIMIZU et al., 2017).

Young's modulus enables the calculation of the change in the dimension of a suture material under tensile loads. Materials with high Young's modulus are more deformable and less elastic. Breaking strength retention is defined as the tensile strength of a suture material in vivo as a percentage of its original strength (BENICEWICZ and HOPPER, 1990). The reported breaking strength retention at 2 weeks after implantation for polydioxanone is $60 \%$, and for polyglyconate $75 \%$ (SHIMIZU et al., 2017). Breaking strength retention (tensile strength of suture in vivo) for PDS II is $80 \%$ after 2 weeks and $60 \%$ after 6 weeks for suture diameters USP $3 / 0$ and larger (HOILE 1983). Polydioxanone appears on the market under several manufactores' names, including PDS ${ }^{\circledR}$ (Ethicon), PDX $^{\circledR}$ (Kruuse) and Surgicryl ${ }^{\circledR}$ (SMI) which were tested in this study.

Catgut is a natural suture material made from the submucosa of the small intestine of sheep or serosa of cow bowels (CHU, 1997). Catgut is absorbed by action of proteolytic enzymes, so it is rapidly absorbed when used in gastrointestinal surgery. HOWES (1928) states that the total loss of tensile strength of plain gut occurs after 12 hours post application in the stomach of a dog. 
The primary aim of this study was to compare the initial tensile strength, tensile strength retention and Young's modulus of the two most commonly used suture materials, polydioxanone and polyglyconate, in gastrointestinal surgery, and to compare them with catgut, as a formerly frequently used suture material. A secondary objective was to compare the tensile strength retention, in the same conditions, of three polydioxanone suture materials produced by different manufacturers, and to develop a rapid system for testing suture quality to be used for general use.

\section{Materials and methods}

In this study were used five samples of monofilament absorbable sutures, polyglyconate, (Maxon ${ }^{\circledR}$, Covidien), polydioxanone (PDS ${ }^{\circledR}$, Ethicon, PDX ${ }^{\circledR}$, Kruuse, Surgicryl ${ }^{\circledR}$, SMI) and Chromic catgut ${ }^{\mathbb{Q}}$, Kruuse, all in diameter USP 2-0.

A total length of each peel pack was sectioned in two parts, approximately $35 \mathrm{~cm}$ each. One half was used to measure tensile strength and initial Young's modulus on day zero. The second part of each sample was implanted into the cadaveric submucosa of the fundus of the stomach wall (Fig. 1). Samples were placed in plastic boxes fully filled with sterile $0.9 \%$ saline solution and left in an incubator at $37{ }^{\circ} \mathrm{C}$ for ten days. Determination of the initial tensile strength, initial Young's modulus and tensile strength retention was conducted for each tested suture material by measuring the ultimate load to failure. The ends of threads that were attached to the jaws of the testing machine were previously drawn into part of the tube of the infusion system in order to protect the suture from mechanical failure at the site of attachment. The measurements of ultimate load to failure were performed on the testing machine (Toyoseiki AT-L-L118B, Japan) on day 0 and day 10 (Fig. 2).

The effects of the type of suture material tested on the data for the examined parameters were tested using analysis of variance (ANOVA). The level of significance of the differences between data of the mean values for the tensile strength and the Young's modulus on day 0 and the day 10 was defined by the $t$-test. The minimum level of significance was defined as $\mathrm{P}<0.05$. 
M. Kreszinger et al.: Tensile strength retention of resorptive suture materials applied in the stomach wall - in vitro study

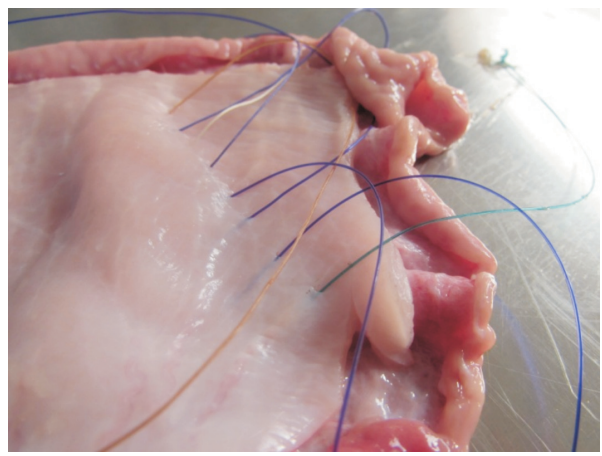

Fig. 1. Suture material placed in cadaveric submucosa of the fundus of the stomach wall, prior to incubation

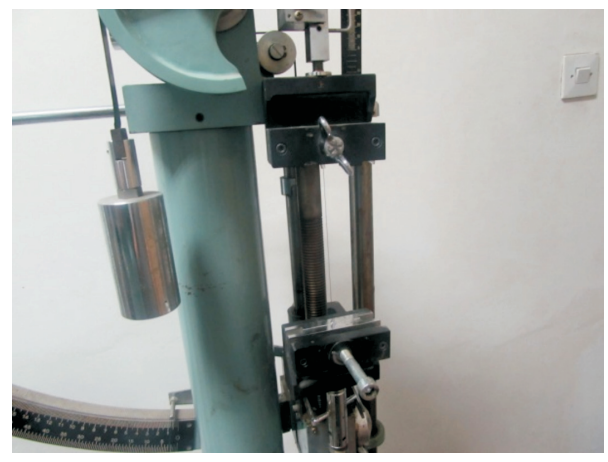

Fig. 2. Suture material placed in the Toyoseiki AT-L-L118B testing machine

\section{Results}

The initial tensile strength for all suture materials was within the interval of 193.73684.29 $\mathrm{MPa}$. It decreased during incubation in the stomach wall so that on day 10 the tensile strength retention was $61.18-483.56 \mathrm{MPa}$. The distribution of these values is presented in Fig. 3.

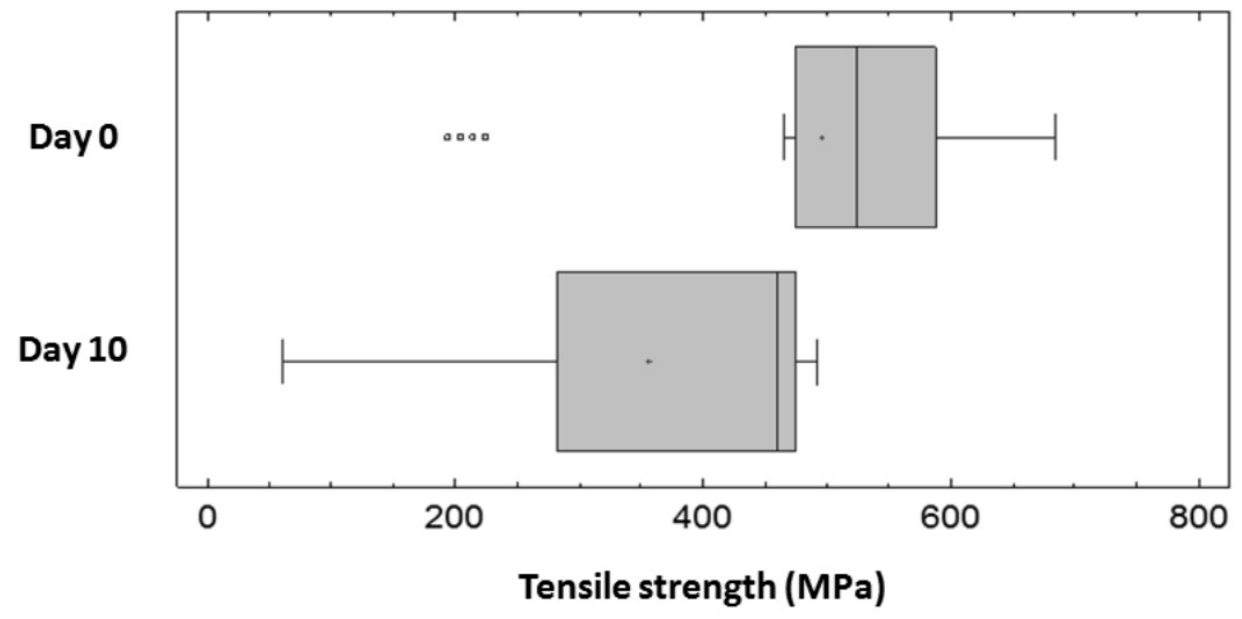

Fig. 3. Distribution of tensile strength on day 0 and day 10 
The Young's modulus of elasticity for all suture materials, on day 0 was in the interval of 632.7 to $1571.85 \mathrm{MPa}$. It decreased during incubation in the stomach wall so that on day 10 it was in the interval of 349.11 to $674.07 \mathrm{MPa}$. The distribution of these values is presented in Fig. 4.

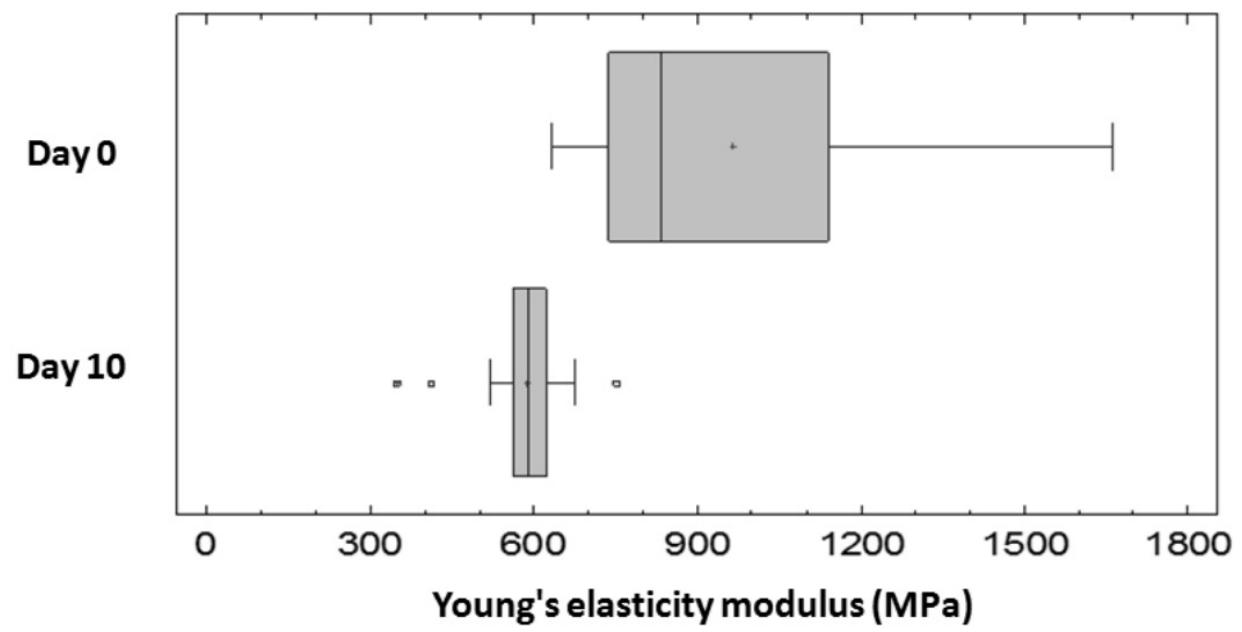

Fig. 4. Distribution of Young's modulus of elasticity on day 0 and day 10

We found significantly lower values of tensile strength and Young's modulus of elasticity on day 0 compared with the same values on day 10 for every tested suture material. Maxon ${ }^{\circledR}$ had the highest tensile strength on both day 0 and day 10 , while Catgut had the lowest tensile strength. Young's modulus of elasticity on day 0 was the highest for Catgut, while at same time it was the lowest for Surgicryl ${ }^{\circledR}$.

The initial tensile strength was highest for $\operatorname{Maxon}^{\circledR}(675.16 \pm 5.8 \mathrm{MPa})$ and lowest for Catgut (212.42 $\pm 12 \mathrm{MPa}$ ). Young's modulus was initially highest for Catgut (1525.5 $\pm 92.7 \mathrm{MPa})$ and lowest for Surgicryl ${ }^{\mathbb{B}}(670.6 \pm 37.3 \mathrm{MPa})$. After 10 days of incubation in the submucosa of the stomach wall, Surgicryl ${ }^{\circledR}$ lost $10.94 \%$ of its initial tensile strength, as opposed to Catgut, that lost $39.03 \%$. After 10 days of incubation Surgicryl ${ }^{\circledR}$ lost only $11.5 \%$ of its initial values of Young's modulus, as opposed to Maxon ${ }^{\circledR}$ that lost $28.6 \%$. Catgut lost $64 \%$ followed by PDX ${ }^{\circledR}$ that lost $39.5 \%$. The results are presented in Table1. 
M. Kreszinger et al.: Tensile strength retention of resorptive suture materials applied in the stomach wall - in vitro study

Table 1. Ultimate load to failure and Young's modulus E of suture materials on day 0 and day 10 after incubation in submucosa of the stomach wall (Mean \pm SEM)

\begin{tabular}{|l|l|c|c|c|c|c|}
\hline & $\begin{array}{c}\text { Suture } \\
\text { material }\end{array}$ & $\begin{array}{c}\text { Day 0 } \\
\mathrm{MPa}\end{array}$ & $\begin{array}{c}\text { Day 10 } \\
\mathrm{MPa}\end{array}$ & $\begin{array}{c}\text { Alteration } \\
\text { MPa }\end{array}$ & Alteration \% & \\
\hline \multirow{4}{*}{$\begin{array}{l}\text { Ultimate } \\
\text { load to } \\
\text { failure } \\
(\mathrm{MPa})\end{array}$} & Maxon & $675.16 \pm 5.8$ & $482.04 \pm 6.9$ & $-193.12 \pm 8.9$ & $-28.6 \pm 1.2$ & $\mathrm{P}<0.05$ \\
\cline { 2 - 8 } & $\mathrm{PDS}$ & $583.08 \pm 5.3$ & $459.39 \pm 9.9$ & $-123.68 \pm 9.5$ & $-21.21 \pm 1.6$ & $\mathrm{P}<0.05$ \\
\cline { 2 - 8 } & $\mathrm{PDX}$ & $478.99 \pm 9.6$ & $291.96 \pm 8.2$ & $-187.04 \pm 12.6$ & $-39.03 \pm 2.1$ & $\mathrm{P}<0.05$ \\
\cline { 2 - 8 } & Curgricryl & $527.66 \pm 9.0$ & $469.88 \pm 9.6$ & $-57.78 \pm 11.0$ & $-10.94 \pm 2.0$ & $\mathrm{P}<0.05$ \\
\hline & Catgut & $212.42 \pm 12.0$ & $74.77 \pm 8.3$ & $-137.65 \pm 5.6$ & $-64.88 \pm 2.4$ & $\mathrm{P}<0.05$ \\
\hline \multirow{4}{*}{$\begin{array}{l}\text { Young's } \\
\text { modulus } \\
\text { E (MPa) }\end{array}$} & Maxon & $831.27 \pm 154.2$ & $543.48 \pm 21.2$ & $-287.78 \pm 152.9$ & $-33.15 \pm 10.0$ & $\mathrm{P}<0.05$ \\
\cline { 2 - 8 } & PDS & $798.32 \pm 57.7$ & $658.15 \pm 21.8$ & $-140.18 \pm 45.5$ & $-17.29 \pm 5.0$ & $\mathrm{P}<0.05$ \\
\cline { 2 - 8 } & SuX & $1000.95 \pm 112.8$ & $599.87 \pm 19.0$ & $-401.08 \pm 108.6$ & $-39.52 \pm 6.1$ & $\mathrm{P}<0.05$ \\
\cline { 2 - 8 } & Catgut & $1525.51 \pm 92.7$ & $546.99 \pm 146.4$ & $-978.51 \pm 183.8$ & $-63.96 \pm 10.3$ & $\mathrm{P}<0.05$ \\
\cline { 2 - 7 } & & $\mathrm{P}<0.05$ & $\mathrm{NS}$ & $\mathrm{P}<0.05$ & $\mathrm{P}<0.05$ & $/$ \\
\hline
\end{tabular}

\section{Discussion}

Our results show that there are huge differences in initial tensile strength between different suture materials, and Young's elasticity modules. The reported breaking strength retention at 2 weeks after implantation for polydioxanone is $60 \%$, and for polyglyconate and GTC 75\% (SHIMIZU et al., 2017). METZ et al. (1990) examined polyglyconate and polydioxanone in a rabbit model. They exposed both materials to body fluids (peritoneum) for 35 days. The initial tensile strength of polyglyconate $\left(\right.$ Maxon $\left.^{\circledR}\right)$ is greater than that of polydioxanone $\left(\mathrm{PDS}^{\circledR}\right)$, but the residual strength of $\left(\right.$ Maxon $\left.^{\circledR}\right)$ decreases more rapidly, so that, after 2 weeks, the residual tensile strength of polydioxanone is greater (METZ et al., 1990). On the basis of our results for the residual strength ten days after incubation in the submucosa of the stomach, we also concluded that the tensile strength of polyglyconate $\left(\right.$ Maxon $^{\circledR}$ ) decreases more rapidly in comparison to polydioxanone sutures. MUFTUOGLU et al. (2004) found that polydioxanone, $\mathrm{PDS}^{\circledR}$ maintained $92 \%$ of its initial tensile strength after 7 days of in vitro exposure to bile, and $89 \%$ after 7 days of exposure to pancreatic juice. In the same study, chromic catgut lost $57 \%$ of initial tensile strength after 7 days of exposure to bile and disintegrated after 7 days of exposure to pancreatic juice. In our study polydioxanone $\left(\right.$ Surgicryl ${ }^{\circledR}$ ) showed the greatest tensile strength retention $(89 \%)$, whereas polyglyconate $\left(\operatorname{Maxon}^{\circledR}\right)$ retained $71.4 \%$ of its initial tensile strength after 10 days of incubation in the submucosa of the stomach. Consequently, the tensile strength of polyglyconate $\left(\right.$ Maxon $\left.^{\circledR}\right)$ and polydioxanone $\left(\right.$ Surgicryl ${ }^{\circledR}$ ) after 10 days of incubation 
in submucosa of the stomach wall, was at the same level. This is in accordance with the results obtained by METZ et al. (1990), mentioned above. The initial tensile strength of 3 tested polydioxanone sutures differed; PDS II ${ }^{\circledR}$ was the strongest $(583.08 \pm 5.3 \mathrm{MPa})$, followed by Surgicryl ${ }^{\circledR}(527.66 \pm 9.0)$, and PDX ${ }^{\circledR}$ (478.99 \pm 9.6$)$. Polydioxanone PDS $\mathrm{II}^{\circledR}$, Ethicon and PDX ${ }^{\circledR}$, Kruuse maintained $79 \%$ and $61 \%$ of their initial tensile strength respectively. This is significantly lower than Surgicryl ${ }^{\circledR}$, which retained $89 \%$ of its initial tensile strength. These differences suggest the diversity of characteristics of suture materials of the same composition, but produced by different manufacturers.

The sharp decline in tensile strength retention of PDX ${ }^{\circledR}$, Kruuse, after 10 days of incubation in the submucosa of the stomach suggests a cautious approach in the selection of this material for stomach or intestine repairs.

Our study showed very low tensile strength retention for catgut, only $75 \mathrm{MPa}$ or $35 \%$ after 10 days of incubation in the submucosa of the stomach. Based on this we may conclude that catgut is an inadequate suture material for gastrointestinal surgery. With Maxon $^{\circledR}$, tensile strength retention was measurable for 42-49 days, while the period for PDS $^{\circledR}$ amounted to 65-80 days (KNOOP et al., 1987).

The lowest initial Young's modulus of elasticity for polydioxanone Surgicryl ${ }^{\circledR}$ $(670.6 \pm 37.3 \mathrm{MPa})$ means that suture material is the least deformable or more elastic in comparison to other tested materials, including Maxon ${ }^{\circledR}$. After 10 days of incubation in the submucosa of the stomach wall, Young's modulus for polyglyconate (Maxon ${ }^{\circledR}$ ) decreased more than for polydioxanone Surgicryl ${ }^{\circledR}$ (33\% versus $\left.11 \%\right)$. At that time there were no significant differences between any of the tested suture materials. Due to the specific nature of the stomach and intestines, such as exposure to high motility and distension, less deformable and more elastic suture materials might be a more appropriate choice for stomach and intestine repair. This could be polydioxanone Surgicryl ${ }^{\circledR}$, at least in the first few days after tissue repair. The high initial Young's modulus of elasticity for polydioxanone $\mathrm{PDX}^{\circledR}(1001 \mathrm{MPa})$ could be an indicator of high deformability and low elasticity, that could be a serious deficiency.

The observations made in this study indicate that, polydioxanone and polyglyconate suture materials are a good choice for gastrointestinal surgery in terms of suture tensile strength retention. Polyglyconate is initially stronger but loses tensile strength more rapidly in comparison to polydioxanone. The tensile strength retention, in the case of implantation in the cadaveric submucosa of the stomach wall, differs significantly between polydioxanone suture materials produced by different manufacturers.

In conclusion, polyglyconate $\left(\right.$ Maxon $\left.^{\circledR}\right)$ has higher initial tensile strength in comparison to polydioxanone Surgicryl ${ }^{\circledR}$. Polydioxanone Surgicryl ${ }^{\circledR}$ has more tensile strength retention and higher initial elasticity in comparison to polyglyconate $\left(\operatorname{Maxon}^{\mathbb{R}}\right)$. 
M. Kreszinger et al.: Tensile strength retention of resorptive suture materials applied in the stomach wall - in vitro study

Further studies are warranted in order to evaluate the tensile strength retention in more physiological conditions, such as a study performed in vivo.

\section{References}

BENICEWICZ, B. C., P. K. HOPPER (1990): Polymers for absorbable surgical sutures-part I. J. Bioact. Compat. Polym. 5, 453-472.

CHU, C. C. (1997): Classification and general characteristics of suture materials. CRC Press 39, 365-371.

FAHIE, M. A. (2014): Gastrotomy. In: Current Techniques in Small Animal Surgery, $5^{\text {th }}$ ed. (Bojrab, M. J., R. Waldron, J. P. Toombs. Eds.). Teton New Media, Jackson, WY, pp. 255-263.

FINN, G. (1981): Healing of incisional wounds in stomach and duodenum: Collagen distribution and relation to mechanical strength. Am. J. Surg. 141, 222-227.

GREENWALD, D., S. SHUMWAY, P. ALBEAR, L. GOTLIEB (1994): Mechanical comparison of 10 suture materials before and after in vivo incubation. J. Surg. Res. 56, 372-373.

HOILE, R. W. (1983): The use of a new suture material (Polydioxanone) in the biliary tract. Ann. Royal Coll. Surg. Engl. 65, 168-175.

HOWES, E. L. (1928): Factors determining the loss of strength of catgut when embedded in tissue. JAMA 90, 530-537.

KNOOP, M, B. LÜNSTEDT, A. THIEDE (1987): Maxon and PDS-evaluation and physical and biologic properties of monofilament absorbable suture materials. Langenbecks Arch. Chir. 371, 13-28.

LAMBORN, P. B., H. B. SOLOWAY, T. MATSUMOTO (1970): Comparison of tensile strength of wounds closed by sutures and cyanoacrylates. Am. J. Vet. Res. 31, 125-132.

METZ, S. A., N. CHEGINI, B. J. MASTERSON (1990): In vivo and in vitro degradation of monofilament absorbable sutures, PDS $^{\circledast}$ and Maxon $^{\circledR}$. Biomaterials 11, 4145-4156.

MUFTUOGLU, T., E. OZKAN, A. SAGLAM (2004): Effect of human pancreatic juice and bile on tensile strength of suture materials. Am. J. Surg. 188, 200-203.

ROUSH, J. K. (2002): Biomaterials and surgical implants. In: Textbook of Small Animal Surgery. $3^{\text {rd }}$ ed. (Slatter, D. Ed). Saunders, Philadelphia, pp.141-148.

SANZ, L. E., J.A. PATTERSON, R. KAMATH, G. WILLETT, S. W. AHMED, A. B. BUTTERFIELD (1988): Comparison of Maxon suture with Vicryl, chromic catgut, and PDS sutures in fascial closure in rats. Obstet. Gynecol. 71 (3 Pt 1), 418-422.

SCHILLER, T. D., E. A. STONE, B. S. GUPTA (1993): In vitro loss of tensile strength and elasticity of five absorbable suture materials in sterile and infected canine urine. Vet. Surg. 22, 208-212.

SHIMIZU, N., J. TARLTON, E. FRIEND, I. DORAN, K. PARSONS (2017): Tensile comparison of polydioxanone, polyglyconate and barbed glycolide-trimethylene carbonate suture in canine cadaveric tensor fascia lata. Vet. Surg. 46, 89-94. 
M. Kreszinger et al.: Tensile strength retention of resorptive suture materials applied in the stomach wall - in vitro study

SMEAK, D. (1998): Selection and use of currently available suture materials and needles. In: Current Techniques in Small Animal Surgery. $4^{\text {th }}$ ed. (Bojrab, M. J., Ed.). Williams \& Wilkins, Philadelphia, pp. 19-26.

KRESZINGER, M., B. TOHOLJ, A. AČANSKI, S. BALOŠ, M. CINCOVIĆ, M. PEĆIN, M. LIPAR, O. SMOLEC: Vučna čvrstoća resorptivnog šivaćeg materijala primijenjenoga u rekonstrukciji stijenke želuca - in vitro istraživanje. Vet. arhiv 88, 235-243, 2018.

Primarni cilj ovog istraživanja bio je odrediti koji je od resorptivnih materijala za šivanje, poliglikonat ili polidioksanon, bolji s obzirom na zadržavanje vučne čvrstoće konca, a nakon implantiranja u submukozu želučane stijenke. Sljedeći je cilj bio usporediti vučnu čvrstoću konaca sastava polidioksanon, različitih proizvođača, u istim uvjetima. Pet uzoraka resorptivnih materijala za šivanje, poliglikonat (Maxon ${ }^{\circledR}$, Covidien), $^{2}$ polidioksanon (PDS ${ }^{\circledR}$, Ethicon, PDX ${ }^{\circledR}$ Kruuse, Surgicryl ${ }^{\circledR}$ SMI), Catgut chromic, Kruuse, svi istoga promjera USP 2-0, implantirani su u sluznicu želučane stijenke lešine kunića tijekom 10 dana. Određivanje vučne čvrstoće izvedeno je nulti i deseti dan. Poliglikonat $\left(\right.$ Maxon $\left.^{\circledR}\right)$ pokazao je najveću početnu vučnu čvrstoću. Nakon 10 dana inkubiranja u submukozi želučane stijenke poliglikonat $\left(\right.$ Maxon $\left.^{\circledR}\right)$ brže je gubio vučnu čvrstoću u usporedbi s koncima sastava polidioksanon, ali je zadržao veću vrijednost vučne čvrstoće. Polidioksanon $\left(\right.$ Surgicry $\left.^{\circledR}\right)$ nakon 10 dana inkubiranja u submukozi želučane stijenke imao je najveći postotak $(91,4 \%)$ zadržavanja početne vučne čvrstoće. Polidioksanon $\left(\mathrm{PDX}^{\circledR}\right)$ zadržao je samo 58,5 \% početne vučne čvrstoće. Polidioksanon Surgicryl ${ }^{\circledR}$ imao je najveći početni Youngov modul elastičnosti.

Ključne riječi: resorptivni materijal za šivanje; poliglikonat; polidioksanon; vučna čvrstoća; želučana stijenka 
